\title{
Development of China C2C E-commerce from the Perspective of Goods Delivery
}

\author{
Hongjiao Fu, Youbei Huang and Xuxu Wei \\ Deptartment of Economic Information Management, School of \\ Information, Renmin University of China, Beijing 100872, P.R. China \\ fuhongiiao@263.net, yopey@263.com,weixuxu2005@263.net
}

\begin{abstract}
As one of the key applied forms on Internet, C2C E-commerce has been growing at a very high speed in China in recent years. Starting from the perspective that $\mathrm{C} 2 \mathrm{C} \mathrm{E}$-commerce consumers pursue low price while retailers try to decrease the cost, by using the methods of sampling survey and case study, the paper will discuss issues about goods delivery cost, delivery time and delivery quality in $\mathrm{C} 2 \mathrm{C}$ E-commerce and compare them with $\mathrm{B} 2 \mathrm{~B} \mathrm{E}$ commerce. According to the result of research, the paper predicts the future development trend of China $\mathrm{C} 2 \mathrm{C} \mathrm{E}$-commerce.
\end{abstract}

\section{Introduction}

The importance of E-commerce has been accepted by more and more people in various circles. The emergency of China $\mathrm{C} 2 \mathrm{C}$ E-commerce mode is marked by the establishment of EBay China Inc. in 1999 and its development is very rapid. With the improvement and maturing of the environment, the transaction volume of China $\mathrm{C} 2 \mathrm{C}$ E-commerce has quickly increased in recent years. In 2001, the transaction volume of China $\mathrm{C} 2 \mathrm{C}$ E-commerce market was merely $\mathrm{RMB} 400$ million. It reached up to RMB 13.71 billion by 2005 with a CAGR of $142.0 \%$ [1]. Today China's C2C E-commerce market is dominated by three major players: Taobao (www.taobao.com), EBay China (www.ebay.com.cn), and Paipai (www.paipai.com).

When the issues of credit and safe online payment become the public's focus, some problems emerged in goods delivery that affect online consumers' behaviors without being noticed. The problems of credit and safe e-payment prevent some consumers from getting into field of E-commerce. To the consumers who use Ecommerce, after crossing the threshold of "credit and safety", they must face another big problem i.e. goods delivery. It is clear that the issue of goods delivery affects the number of consumers who would participate in E-commerce. Starting from the perspective that $\mathrm{C} 2 \mathrm{C}$ consumers pursue low price while retailers try to decrease the cost, the paper will discuss issues about delivery cost, delivery time and delivery

Please use the following format when citing this chapter:

Fu, II., Iuang, Y., Wci, X., 2007, in IFIP International Federation for Information Processing, Volume 251, Integration and Innovation Orient to E-Socicty Volumel, Wang, W. (Eds), (Boston: Springcr), pp. 179-186. 
quality in C2C E-commerce and compare them with B2B E-commerce by using the methods of sampling survey and case study. Through comparison and analysis, the paper discusses the future development trends of $\mathrm{C} 2 \mathrm{C}$ E-commerce in China.

The data used in this research came from 107 survey questionnaires we sent out and in-depth interviews with related retailers and consumers. The survey consists of a survey of $\mathrm{C} 2 \mathrm{C}$ consumer and a survey of $\mathrm{C} 2 \mathrm{C}$ retailer. The targets of the survey are located in seven cities including Beijing, Shanghai, Guangzhou, Qingdao, Chengdu, Hangzhou, and Harbin.

\section{Related concepts in C2C E-commerce}

Some concepts related to $\mathrm{C} 2 \mathrm{C}$ E-commerce will be involved in this paper, so we will explain them in this section.

\subsection{Structure of goods price}

Currently, goods price of $\mathrm{C} 2 \mathrm{C}$ E-commerce consists of two parts: retail price and delivery cost. Retail price has same meaning as it in traditional business which refers to sale price of a good. Delivery cost refers to the cost that needs to be paid to the company who delivers goods for consumers. The main delivery entities in China are China Post and express delivery companies. The sum of the retail price and delivery cost is called purchase price paying to the retailer by the consumer.

\subsection{Auction way of the goods}

There are two ways for consumers to purchase goods online including "fixed price" and "auction price". "Fixed price" means the retailers sell the goods in a regular price and no bargaining. "Auction price" means the retailers offer the starting price and price bid increment when they sell the goods. The consumers input the lowest price they want or input the highest price they can accept then waiting for the processing of the auction system. When the auction is finished, the consumer who bid the highest price will take the good.

\subsection{Ways of goods delivery}

Now the ways of delivering goods in China C2C E-commerce include: Regular Mail, EMS and Express Delivery. "Regular mail" refers to delivering the goods in the form of an ordinary parcel or print design through China Post from the retailer to the consumer. "EMS" refers to Express Mail Service through China Post mainly by airplane to speed the delivery up. Depending on the distance, the mail or parcel will be sent to destination from one day to seven days. "Express Delivery" refers to the express delivery service offered by other express delivery companies except China Post. They have their own networks and mainly are private companies, such as ZJS (www.zjs.com.cn). There are about one thousand express companies in China now. 


\subsection{Logistics distribution system of E-commerce in China}

There are three ways of logistics distribution in current China E-commerce [2]: (1) Establishing their own distribution channels and facilities to deliver goods by themselves. The E-commerce companies set up storage centers and distribution centers where online consumers are densely populated. (2) Entrusting the third party professional logistics distribution institutions to deliver goods. (3) Cooperating with chain department stores and China Post EMS to complete goods delivery together.

\section{Study on goods delivery of China C2C E-commerce}

Goods delivery has a great effect on operation cost of E-commerce companies. Most C2C E-commerce consumers are scattered group. Their orders are random and scattering that leads to small delivery batch and high delivery cost. Now "goods delivery" has become top-four problem of "the most untrustable issue of $\mathrm{C} 2 \mathrm{C}$ online shopping" after goods quality, sellers' credit and payment [1]. Next this paper will discuss China future development tendency of $\mathrm{C} 2 \mathrm{C}$ E-commerce from the perspective of goods delivery cost, delivery time and delivery quality.

\subsection{Delivery cost}

According to the related report [1], 78.4\% of online consumers choose $\mathrm{C} 2 \mathrm{C}$ website to shop for the reason of "relatively cheap price". By the end of 2006 , the young people between 18 and 24 years old account for $35.2 \%$ of all Internet users. Main consumers of $\mathrm{C} 2 \mathrm{C} \mathrm{E}$-commerce are those young people [3]. However, most of them earn a low or no income, so pursuing cheap price is their main intention of online shopping. In fact, when consumers shopping on $\mathrm{C} 2 \mathrm{C}$ websites, they usually find that most goods always have similar purchase prices as traditional stores. Sometimes the price is even a little higher than offline shopping. Why this happens? The main reason is that online shopping has extra delivery cost.

Current $\mathrm{C} 2 \mathrm{C}$ online transactions are mainly cheap goods and the profits of these goods are very little. If adding delivery cost into the purchase price, the consumers will not take the advantage of favorable prices of online shopping, so they naturally hesitate when making online shopping decisions.

\subsubsection{The analysis of goods delivery cost of B2C E-commerce}

As mentioned above, there are three ways of distribution adopted by E-commerce Company. The first way is mainly used in large or medium-sized companies. Taking the famous B2C website Joyo.com as an example, in March of 2002, it established Beijing Century Joyo Express Delivery Service Corporation, supplying the services including "home-delivery" and "cash on delivery" in some large cities of China [4].

Meanwhile, Joyo.com also uses the second and the third way. Joyo delivers goods by China Post in the places where no their home delivery service. However, according to postage standard of regular post service, the more goods consumers buy, the higher the delivery cost is. Sometimes delivery cost might be over one hundred RMB or exceed the value of the good itself. Such high postage restricts consumers' 
enthusiasm of online shopping. To solve this problem, Joyo chose to cooperate with China Post to reduce the postage since November of 2002. For a regular mail within mainland China, no matter how many goods, it only costs RMB 5. If buyers spend more than RMB 99 at one time, then they don't need to pay delivery fee [4].

In fact, like Joyo.com, most B2C E-commerce websites have preferential delivery charge. Such as Dangdang.com, it charges free when consuming over RMB 99 one time [5]. The free level of Bertelsmann (www.bol.com.cn) is even as low as RMB 38 [6]; 2688 website offers free delivery service in most cities of China [7]. The decrease of delivery cost stimulates consumers to shop on such websites.

\subsubsection{The analysis of goods delivery cost of C2C E-commerce}

$\mathrm{C} 2 \mathrm{C}$ E-commerce retailers are individuals. Mostly $\mathrm{C} 2 \mathrm{C}$ retailers sell small amount of goods with high frequency and disperse destinations. As a result, $\mathrm{C} 2 \mathrm{C}$ retailers haven't enough power to setup their own delivery teams, or sign a long-time contract with China Post or delivery companies. In most cases, they would choose the second or third method for delivery, so the delivery fee must be in accordance with China Post or delivery companies, so the delivery cost is high and hard to reduce.

We samples retail price and delivery cost of different kinds of goods in different $\mathrm{C} 2 \mathrm{C}$ online shops. According to our investigation data, we can get the relationship between delivery cost and retail price, shown as Fig.1. Through calculation and analysis, we get a cubic polynomial $Y=4 \times 10^{-11} \mathrm{X}^{3}-10^{-6} \mathrm{X}^{2}+0.0101 \mathrm{X}+9.9404$. Here $\mathrm{X}$ represents retail price and $\mathrm{Y}$ represents delivery cost (regular mail).

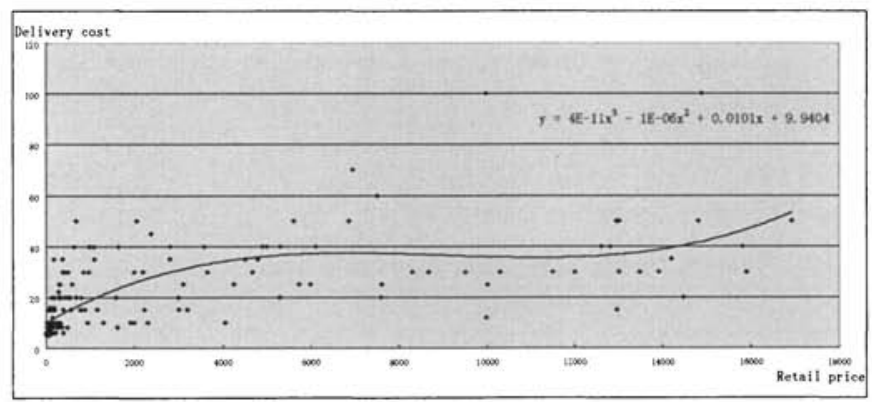

Figure.1. The relationship between delivery cost and retail price

Through colligated analysis of all the data above, we can get the delivery costs with different retail price region, as shown in Table 1.

Table 1. The regular mail of different retail price (regular mail)

\begin{tabular}{|c|l|l|l|l|l|l|}
\hline Retail price & $\begin{array}{l}0-15 \\
\text { Yuan }\end{array}$ & $\begin{array}{l}16-50 \\
\text { Yuan }\end{array}$ & $\begin{array}{l}50-300 \\
\text { Yuan }\end{array}$ & $\begin{array}{l}\text { 300-500 } \\
\text { Yuan }\end{array}$ & $\begin{array}{l}500-5000 \\
\text { Yuan }\end{array}$ & $\begin{array}{l}\text { Above } \\
\text { Yuan }\end{array}$ \\
\hline $\begin{array}{c}\text { Delivery } \\
\text { cost }\end{array}$ & $\begin{array}{c}5 \\
\text { Yuan }\end{array}$ & $6-8$ Yuan & $8-10$ Yuan & $10-20$ Yuan & 20-35 Yuan & 35-50 Yuan \\
\hline
\end{tabular}

Here, we advance the concept "Peijiabi", which refers to the rate of delivery cost and retail price. As shown in Fig.1, the slope of this cubic curve is "Peijiabi". We 
can see that the higher the retail price is, the smaller the slope is. Then we conclude that the "Peijiabi" of goods with high retail price is small and vice versa.

In the questionnaires, we investigate consumers about "Peijiabi". $35 \%$ of consumers will choose to give up shopping online if "Peijiabi" beyond 0.5 . When the rate is between 0.1 and $0.4,23 \%$ will choose to compare the price with the goods nearby then make the decision. As the rate is smaller than 0.1 , only $2 \%$ will abandon. We can conclude that because of the high delivery cost, the market share of C2C Ecommerce has shrunk greatly. Due to low retail price, the "Peijiabi" of small-ticket items is often high. Those data confirm that the delivery cost is the key factor to influence small-ticket commodity sales online.

\subsubsection{The effect of delivery cost on C2C E-commerce}

At present, the goods delivery costs are centralized mainly between RMB 5 and 20 . The delivery cost almost equals to retail price for goods cheaper than RMB 20. This phenomenon slacks down the price advantage of $\mathrm{C} 2 \mathrm{C}$ E-commerce and reduce enthusiasm of shopping online. However, small-ticket goods sell well now with two reasons: (1) many consumers are still suspicious of $\mathrm{C} 2 \mathrm{C} \mathrm{E}$-commerce; they usually buy some small-ticket items at the first time; (2) there aren't the goods nearby consumers want. But E-commerce platform collect many sellers who come from the whole country even the whole world, so buyers are easier to find the items they like.

However, with economic globalization and growing up of E-commerce, no matter online or offline, the goods choices for consumers will be more. Moreover, B2C E-commerce companies can cooperate with distribution companies to reduce the cost by signing long-term agreement. Obviously, if $\mathrm{C} 2 \mathrm{C}$ companies can't lower their delivery cost, the development of $\mathrm{C} 2 \mathrm{C}$ E-commerce will be restricted hugely.

\subsection{Delivery time}

The E-commerce consumer must wait for receiving goods after making an order. According to the survey from CNNIC [8], many people think the biggest problem is "channels not flowing easily thus taking too much time to send goods", $21.6 \%$ of online buyers think that delivery time needs to be shorten. During our interviews with $\mathrm{C} 2 \mathrm{C}$ consumers, we find that almost half of them give up shopping online due to long delivery time that they can't bear.

\subsubsection{The Analysis of goods delivery time in China}

Different delivery methods lead to different length of delivery time. Regular mails usually need one or two weeks depending on the distance from sending place to receiving place and don't supply home-delivery service. EMS and express delivery need less time. Goods can arrive at the same day if sending place and receiving place in the same city. If they are in different cities, it depends on whether it is a provincial capital, small-medium cities or remote district. Usually EMS needs two to seven days, while express delivery needs one to three days.

\subsubsection{Goods delivery time of $\mathrm{C} 2 \mathrm{C}$ E-commerce}

In our survey, most consumers think regular mail and EMS take too long time, so they would choose express delivery service. $16.7 \%$ of consumers choose "The main 
delivery way is express delivery when shopping on C2C website". They all express that they choose express delivery just for getting their items as quickly as possible.

However, the common price is RMB 10 per kilogram through express company; the minimum charge of EMS is RMB 20. Such expensive delivery fees make many consumers lose the interests to shop on $\mathrm{C} 2 \mathrm{C}$ website.

\subsubsection{Goods delivery time of B2C E-commerce}

Unlike $\mathrm{C} 2 \mathrm{C}$ E-commerce, $\mathrm{B} 2 \mathrm{C}$ retailers have their own distribution teams. Except regular mail and EMS, their express delivery includes home-delivery service and urgent home-delivery service. For regular mail and EMS, both $\mathrm{B} 2 \mathrm{C}$ and $\mathrm{C} 2 \mathrm{C}$ rely on China Post, so there is no difference in delivery time. But urgent home-delivery service of $\mathrm{B} 2 \mathrm{C}$ equals with express delivery in $\mathrm{C} 2 \mathrm{C}$. In fact, urgent home-delivery service needs to pay extra RMB 10 to 15 which consumers are not willing to pay. Home-delivery service time is between regular mails and express delivery in $\mathrm{C} 2 \mathrm{C}$. In Beijing or Shanghai, home-delivery service requires 12 to 24 more hours than $\mathrm{C} 2 \mathrm{C}$ express delivery. In other places, home-delivery service needs 1 to 6 days or more.

\subsubsection{The effect of delivery time on C2C E-commerce}

We know from above analysis that the delivery time of $\mathrm{C} 2 \mathrm{C}$ has more advantage. However, home-delivery service in $\mathrm{B} 2 \mathrm{C}$ only charges $\mathrm{RMB} 5$, which is lower than express delivery in $\mathrm{C} 2 \mathrm{C}$. If delivery times are same, especially to consumers in Beijing and Shanghai, the advantage of $\mathrm{C} 2 \mathrm{C}$ delivery time isn't obvious.

\subsection{Delivery quality}

The feature of E-commerce determines that goods delivery needs a certain time. When goods come to consumers at last, the quality may slip up due to mistakes in the delivery process. Both sides of transaction couldn't control this. According to the related report [8], the unpleasant experiences caused by delivery issues take $22.5 \%$, $24.3 \%$, and $14.7 \%$ separately in Taobao, EBay, and Paipai.

\subsubsection{The analysis of goods delivery quality in current C2C E-commerce}

During delivering process, damage of goods is easiest-to-appear. In our survey, many consumers complained that frangible goods, such as glass, are easy to be damaged. which also make baneful influence on goods delivery. They also said some deliverers are unethical and sometimes exchange valuable goods like cell phones. Retailers can only complain to express companies or post office. Maybe they can get compensation, but it is hard to regain all money.

If delivery mistakes can't be avoided, both sellers and buyers should get compensation. But on the community forums of Taobao, EBay and Paipai, many consumers complain that sellers reject to compensate when goods are damaged. Meanwhile, many $\mathrm{C} 2 \mathrm{C}$ retailers complain that post office or express companies also reject to compensate when goods damaged. Thus, it's very important to issue related bylaws to avoid these things to happen.

In fact, most $\mathrm{C} 2 \mathrm{C}$ retailers belong to a small capital business. When they can't get compensation, it is natural for them to assume the loss with consumers, even 
reject to compensate consumers. This situation makes bad influence on retailers and blows the passion of consumers to shop on $\mathrm{C} 2 \mathrm{C}$ website.

\subsubsection{The analysis of goods delivery quality in current B2C E-commerce}

At first, B2C E-commerce companies have their own delivery team or a long-term cooperation with the third party logistics distribution express companies. Once mistakes occur in delivery, it's easy to find person in charge and compensate according to relevant provisions. Secondly, B2C E-commence websites have their own provisions about after-sale services. Once there are qualities issues in delivery, consumers can claim for compensation according to relevant provisions.

In $\mathrm{C} 2 \mathrm{C}$ E-commence, retailers often reject or require consumers to bear delivery fees when consumers ask for return of goods. However, B2C E-commence websites have correlative return sales policy. For example, Joyo makes detailed explanation: "Joyo.com promises that they will supply return service with whole refund if the goods and packaging keep the original state within 15 days from receiving day"; "for the returned purchase due to goods quality or other causes of Joyo, delivery fees and payment for goods are returned to consumers together." [9]

\subsubsection{The influence of goods delivery quality on C2C E-commence}

The delivery quality is the instable and unpredictable factor in C2C E-commence. After consumers accept goods retail price, delivery fee and delivery time, delivery quality will directly influence their satisfaction degree and the enthusiasm to $\mathrm{C} 2 \mathrm{C}$.

So besides packing goods more scrupulously, C2C retailers should actively contact with express delivery companies with good reputation. For those large scale $\mathrm{C} 2 \mathrm{C}$ retailers, they should sign contracts with a fixed express delivery company which can reduce delivery fees and make delivers more responsibly.

\section{Conclusion}

According to above investigation and analyses, we can conclude that B2C Ecommerce gains more advantages over $\mathrm{C} 2 \mathrm{C}$ E-commerce in reducing delivery cost and delivery time, and in improving delivery quality. However, most consumers are inclined to shop on $\mathrm{C} 2 \mathrm{C}$ websites rather than $\mathrm{B} 2 \mathrm{C}$ websites. The main reasons for that can be summarized as follows: (1) China B2C E-commerce is still underdeveloped. The market scale is far smaller than that of $\mathrm{C} 2 \mathrm{C}$. From our survey we found that the reason of consumers not choosing to shop on B2C websites is because many consumers know little about those websites and their preferential terms of delivery fees; (2) generally, retail prices on $\mathrm{C} 2 \mathrm{C}$ E-commerce websites are lower than $\mathrm{B} 2 \mathrm{C}$ websites, and the types of goods sold on $\mathrm{C} 2 \mathrm{C}$ websites are much more than those sold on B2C websites. As consumers can't find what they need nearby or on $\mathrm{B} 2 \mathrm{C}$ websites, they seem to resort to search and purchase the goods on $\mathrm{C} 2 \mathrm{C}$ websites.

However, from the perspective of economizing, both $\mathrm{B} 2 \mathrm{C}$ and $\mathrm{C} 2 \mathrm{C}$ E-commerce retailers will try to reduce cost and lower the price to attract customers. If consumers know well about $\mathrm{C} 2 \mathrm{C}$ and $\mathrm{B} 2 \mathrm{C}$ E-commerce, and goods prices are similar, the delivery cost will be the deciding factor. According to the above analysis, B2C Ecommerce has more advantages in delivering cost. 
In most cases, prices of goods sold on B2C E-commerce websites are higher than those on the $\mathrm{C} 2 \mathrm{C}$ E-commerce websites. For customers, the biggest concern now is the purchase price, including retail price and delivery fee. Sometimes there are few differences between $\mathrm{B} 2 \mathrm{C}$ E-commerce with higher retail price and lower delivery fee and $\mathrm{C} 2 \mathrm{C}$ E-commerce with lower retail price and higher delivery fee. Considering the credit and the guarantee of high quality goods of B2C E-commerce companies, consumers are more likely to shop on a B2C E-commerce website. Thus, in order to get a certain market share, $\mathrm{C} 2 \mathrm{C}$ E-commerce websites will need to lower retail price or reduce the delivery cost. Some large-scale retailers would like to imitate management pattern of B2C E-commerce companies, making a contract with a local post office or an express delivery company to reduce delivery cost. But for smallscale retailers, they have to cut price further. If the goods prices are close to, even lower than the cost price, the retailers will choose to withdraw from $\mathrm{C} 2 \mathrm{C} \mathrm{E}$ commerce market. Therefore, from the perspective of retailers, the development of C2C E-commerce will be hindered and the market share will shrink.

Fortunately, it is clear that $\mathrm{C} 2 \mathrm{C}$ E-commerce would not disappear. In the future, C2C E-commerce websites will sell unique goods which are customized and not easy to produce on a large scale, such as signature of a movie star, a book published 100 years ago, etc. These goods satisfy the individual needs of consumers. They will not think too much and even ignore delivery fees when buying. In other words, the $\mathrm{C} 2 \mathrm{C}$ E-commerce websites will concentrate on individualized goods, while the best sellers or popular goods will be sold on B2C E-commerce websites which are superior in both price and delivery fee.

\section{Reference:}

1. Shanghai iResearch Co., Itd., 2005 China C2C Ecommerce Research Report, 2006. 2. L. Zhao, R.X Cai and Y. Cui, "Analysis on logistic distribution of E-commerce", Industrial Technology Economy, 9, 45-46(2006).

3. China Internet Network Information Center (CNNIC), The 19th Survey Report on Statistical Reports on the Internet Development in China, Jan 2007.

4. Http://www. joyo.com.

5. Http://www.dangdang.com.

6. Http://www.bol.com.cn.

7. Http://www.365ebuy.com/Merchant_Page/2688.htm.

8. China Internet Network Information Center (CNNIC), 2006 online shopping report of China C2C E-commerce, 2007.

9. Delivery time, delivery fee standard and return policy, http:/www.joyo.com/help. [2007-4-23]. 